\title{
Lycopodium Alkaloids from Palhinhaea cernua
}

\author{
Fu-Wei Zhao, ${ }^{a, b}$ Qian-Yun Sun, ${ }^{c}$ Fu-Mei Yang, ${ }^{c}$ Ji-Feng Luo, ${ }^{a}$ Guang-Wan Hu, ${ }^{a}$ \\ Fang Liu, ${ }^{d}$ Yue-Hu Wang ${ }^{*, a}$ and Chun-Lin Long ${ }^{*, a, e}$
}

${ }^{a}$ Key Laboratory of Economic Plants and Biotechnology, Kunming Institute of Botany, Chinese Academy of Sciences, Kunming 650201, People's Republic of China

${ }^{b}$ Graduate University of Chinese Academy of Sciences, Beijing 100049, People's Republic of China

${ }^{c}$ Key Laboratory of Chemistry for Natural Products, Guizhou Province and Chinese Academy of Sciences, Guiyang 550002, People's Republic of China

${ }^{d}$ College of Landscape and Horticulture, Yunnan Agricultural University, Kunming 650201, People's Republic of China

${ }^{e}$ College of Life and Environmental Sciences, Minzu University of China, Beijing 100081, People's Republic of China

\begin{abstract}
Dois novos alcaloides tipo-licopódio, acetil-licoposerramina $\mathrm{M}$ e palcernina A foram isolados de extratos de plantas inteiras de Palhinhaea cernua L. juntamente com dez compostos previamente identificados. As estruturas dos dois novos compostos foram elucidadas por métodos espectroscópicos e difratometria de Raios X de monocristal usando o parâmetro Flack.
\end{abstract}

Two new Lycopodium alkaloids, acetyllycoposerramine $\mathrm{M}$ and palcernine A were isolated from whole plant extracts of Palhinhaea cernua L. together with ten previously identified compounds. The structures of the new compounds were elucidated by spectroscopic methods and single-crystal $\mathrm{X}$-ray diffraction analyses using the Flack parameter.

Keywords: Lycopodiaceae, Palhinhaea cernua, Lycopodium alkaloids

\section{Introduction}

Palhinhaea cernua L. (syn. Lycopodium cernuum (L.); Lepidotis cernua (L.) P. Beauv.; Lycopodiella cernua (L.) Pic. Ser.), found in both the Flora of North America and the Flora of China, ${ }^{1}$ is a member of the Lycopodiaceae family. The species is traditionally used to heal contusions, scalding and rheumatism by the Chinese people and is broadly distributed in Eastern and Southern China. ${ }^{2}$ The chemical constituents of the genus Lycopodium (sensu lato) plants are mainly Lycopodium alkaloids which are quinolizine or pyridine and $\alpha$-pyridone type alkaloids. ${ }^{3-10}$ Some of these alkaloids inhibit acetylcholinesterase (AChE) and provide a challenge for total synthesis. ${ }^{9-10}$ In our previous research on this plant, palhinine $\mathrm{A}$, a novel $\mathrm{C}_{16} \mathrm{~N}$-type alkaloid was isolated. ${ }^{9} \mathrm{We}$ now report the isolation and structural elucidation of two new Lycopodium alkaloids (1-2) along with ten previously identified compounds (Figure 1), namely, lycoflexine

*e-mail: long@mail.kib.ac.cn, wangyuehu@ mail.kib.ac.cn.
$N$-oxide (3) $)^{8}$, lycoflexine (4), ${ }^{11}$ lycodine (5), ${ }^{12} \alpha$-obscurine (6), ${ }^{12}$ dehydroisofawcettiine (7), ${ }^{13,14}$ lycopodine (8), ${ }^{14}$ 5-acetyllycofoline (9), ${ }^{15}$ acetylfawcettiine $(\mathbf{1 0}),{ }^{16,17}$ cernuine (11) ${ }^{18}$ and lycocernuine (12). ${ }^{18}$

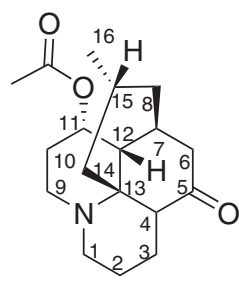

1

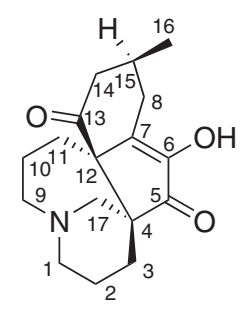

2
Figure 1. The structures of compounds 1-2.

\section{Results and Discussion}

Acetyllycoposerramine M (1) was obtained as a colorless columnar crystal (mp 197-198 ${ }^{\circ} \mathrm{C}$ ). A molecular formula $\left(\mathrm{C}_{18} \mathrm{H}_{27} \mathrm{NO}_{3}\right)$ was assigned by HREIMS (electrospray 
ionization mass spectrometric) analysis (observed $[\mathrm{M}]^{+}$ at $\mathrm{m} / \mathrm{z}$ 305.1995, calcd. [M] $\left.{ }^{+}: 305.1991\right)$, implying six degrees of unsaturation. The IR (infrared) spectrum showed absorptions for ester $\left(1695 \mathrm{~cm}^{-1}\right)$ and keto $\left(1733 \mathrm{~cm}^{-1}\right)$ carbonyl groups. One singlet $\left(\delta_{\mathrm{H}} 2.09,3 \mathrm{H}\right)$ and one doublet $\left(\delta_{\mathrm{H}} 0.88,3 \mathrm{H}, J 6.3 \mathrm{~Hz}, \mathrm{H}_{3}-16\right)$ for two methyl groups were observed in ${ }^{1} \mathrm{H}$ NMR (nuclear magnetic resonance) spectrum of $\mathbf{1}$ (Table 1). Meanwhile, signals of 18 carbons were recorded in the ${ }^{13} \mathrm{C}$ NMR and DEPT (distortionless enhancement by polarization) spectra (Table 2), including the presence of one ester carbonyl $\left(\delta_{\mathrm{C}} 170.3\right)$, one keto carbonyl $\left(\delta_{\mathrm{C}} 214.4, \mathrm{C}-5\right)$, one $\mathrm{sp}^{3}$ quaternary, five $\mathrm{sp}^{3}$ methine, eight $\mathrm{sp}^{3}$ methylene and two methyl groups. Specifically, the signals of an oxygenated methine group were recorded at $\delta_{\mathrm{H}} 5.23$ (ddd, $\left.J 2.9,2.9,2.9 \mathrm{~Hz}, \mathrm{H}-11\right)$ and $\delta_{\mathrm{C}} 72.3(\mathrm{C}-11)$. The above mentioned analyses suggested that 1 was a lyopodine alkaloid, and shared a similar planar structure with the known Lycopodium alkaloid, lycoposerramine M. ${ }^{19}$ Differentiations between the two compounds were observed in that the additive signals $\left(\delta_{\mathrm{H}}\right.$ $2.09,3 \mathrm{H}, \mathrm{s} ; \delta_{\mathrm{C}} 22.0$ and 170.3) for an acetyl group appeared

Table 1. ${ }^{1} \mathrm{H}$ NMR data of compounds 1-2 $(\delta$ in ppm, $J$ in $\mathrm{Hz})$

\begin{tabular}{|c|c|c|}
\hline No. & $\mathbf{1}^{\mathrm{a}}$ & $2^{\mathrm{b}}$ \\
\hline 1a & $3.42(\mathrm{dd}, 14.2,3.4)$ & $3.09(\mathrm{~m})$ \\
\hline $1 b$ & $2.64(\mathrm{~m})$ & $2.93(\mathrm{~m})$ \\
\hline $2 \mathrm{a}$ & $1.89(\mathrm{~m})$ & $2.51(\mathrm{dd}, 14.8,4.0)$ \\
\hline $2 b$ & $1.51(\mathrm{~m})$ & $1.34(\mathrm{~d}, 13.4)$ \\
\hline $3 a$ & $2.13(\mathrm{~m})$ & $2.29(\mathrm{~m})$ \\
\hline $3 b$ & $1.59(\mathrm{ddd}, 13.6,13.6,4.4)$ & $1.99(\mathrm{dd}, 14.8,9.4)$ \\
\hline 4 & $3.24(\mathrm{dd}, 12.0,2.9)$ & \\
\hline $6 a$ & $2.76(\mathrm{dd}, 16.6,6.7)$ & \\
\hline $6 b$ & $2.23(\mathrm{~d}, 16.6)$ & \\
\hline 7 & $2.33(\mathrm{~s})$ & \\
\hline $8 \mathrm{a}$ & 1.69 (br. d, 13.0) & $2.90(\mathrm{~m} ; \beta)$ \\
\hline $8 b$ & $1.35(\mathrm{ddd}, 12.7,12.7,3.4)$ & $2.66(\mathrm{dd}, 15.1,8.0 ; \alpha)$ \\
\hline $9 \mathrm{a}$ & $3.37(\mathrm{~m})$ & $2.99(\mathrm{~m})$ \\
\hline $9 b$ & $2.61(\mathrm{~m})$ & $2.82(\mathrm{~m})$ \\
\hline $10 \mathrm{a}$ & $2.10(\mathrm{~m})$ & $2.15(\mathrm{~m})$ \\
\hline $10 \mathrm{~b}$ & $1.98(\mathrm{~m})$ & $1.41(\mathrm{~m})$ \\
\hline $11 \mathrm{a}$ & $5.23(\mathrm{ddd}, 2.9,2.9,2.9)$ & $2.28(\mathrm{~m} ; \alpha)$ \\
\hline $11 b$ & & $1.65(\mathrm{dd}, 14.7,11.8 ; \beta)$ \\
\hline 12 & $1.85(\mathrm{~m})$ & \\
\hline $14 \mathrm{a}$ & $2.66(\mathrm{~m})$ & $2.49(\mathrm{dd}, 14.8,4.0 ; \alpha)$ \\
\hline $14 b$ & $1.09(\mathrm{dd}, 13.1,13.1)$ & $1.97(\mathrm{dd}, 14.8,9.4 ; \beta)$ \\
\hline 15 & $1.54(\mathrm{~m})$ & $2.19(\mathrm{~m})$ \\
\hline 16 & $0.88(3 \mathrm{H}, \mathrm{d}, 6.3)$ & $0.90(3 \mathrm{H}, \mathrm{d}, 6.7)$ \\
\hline $17 \mathrm{a}$ & & $3.10(\mathrm{~m})$ \\
\hline $17 \mathrm{~b}$ & & $2.99(\mathrm{~m})$ \\
\hline $\mathrm{OCCH}_{3}$ & $2.09(3 \mathrm{H}, \mathrm{s})$ & \\
\hline $6-\mathrm{OH}$ & & 12.19 (br. s) \\
\hline
\end{tabular}

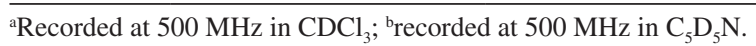

Table 2. ${ }^{13} \mathrm{C}$ NMR data of compounds 1-2 ( $\delta$ in ppm)

\begin{tabular}{lcc}
\hline No. & $\mathbf{1}^{\mathrm{a}}$ & $\mathbf{2}^{\mathrm{b}}$ \\
\hline 1 & $47.2 \mathrm{t}$ & $52.7 \mathrm{t}$ \\
2 & $19.4 \mathrm{t}$ & $21.1 \mathrm{t}$ \\
3 & $20.0 \mathrm{t}$ & $29.3 \mathrm{t}$ \\
4 & $45.4 \mathrm{~d}$ & $54.0 \mathrm{~s}$ \\
5 & $214.4 \mathrm{~s}$ & $203.8 \mathrm{~s}$ \\
6 & $44.4 \mathrm{t}$ & $149.1 \mathrm{~s}^{\mathrm{c}}$ \\
7 & $35.1 \mathrm{~d}$ & $145.0 \mathrm{~s}$ \\
8 & $44.3 \mathrm{t}$ & $28.4 \mathrm{t}$ \\
9 & $42.1 \mathrm{t}$ & $57.7 \mathrm{t}$ \\
10 & $31.0 \mathrm{t}$ & $26.1 \mathrm{t}$ \\
11 & $72.3 \mathrm{~d}$ & $34.0 \mathrm{t}$ \\
12 & $46.8 \mathrm{~d}$ & $61.7 \mathrm{~s}$ \\
13 & $58.9 \mathrm{~s}$ & $210.0 \mathrm{~s}$ \\
14 & $43.8 \mathrm{t}$ & $48.9 \mathrm{t}$ \\
15 & $25.5 \mathrm{~d}$ & $27.4 \mathrm{~d}$ \\
16 & $22.8 \mathrm{q}$ & $21.7 \mathrm{q}$ \\
17 & & $57.8 \mathrm{t}$ \\
$\mathrm{OCCH}_{3}$ & $170.3 \mathrm{~s}$ & \\
$\mathrm{OCCH}_{3}$ & $22.0 \mathrm{q}$ & \\
\hline
\end{tabular}

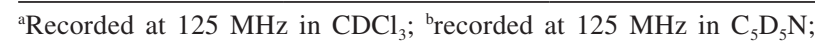
'detected by HMBC.

in the ${ }^{1} \mathrm{H}$ and ${ }^{13} \mathrm{C}$ NMR spectra of $\mathbf{1}$, and the presence of a chemical shift of H-11 in $\mathbf{1}$ was downshifted compared with that of the known compound $\left(\delta_{\mathrm{H}} 4.22\right) .{ }^{19}$ Therefore, it could be speculated that 1 was the acetylated derivative of lycoposerramine $\mathrm{M}$. This was confirmed by the presence of the cross peak between $\mathrm{H}-11$ and ester carbon in the HMBC (heteronuclear multiple bond correlation) spectrum of 1 (Figure 2).
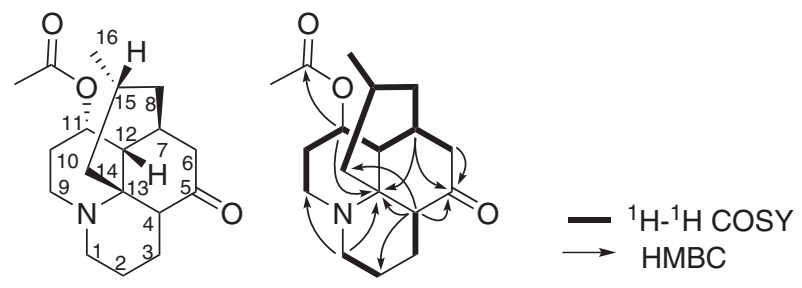

Figure 2. ${ }^{1} \mathrm{H}-{ }^{1} \mathrm{H}$ COSY and HMBC correlations of 1.

To elucidate the absolute configuration, the crystals of 1 were isolated from a mixed solution of petroleum ether/ $\mathrm{Me}_{2} \mathrm{CO}(9: 1)$, and single-crystal X-ray crystallographic analysis was performed (Figure 3 ). The results of the analysis revealed the absolute configuration of $\mathbf{1}$ to be $4 R$, $7 R, 11 R, 12 R, 15 R$ in light of the Flack parameter of $0.0(2)$, using anomalous dispersion with copper radiation. ${ }^{20-22}$ Finally, $\mathbf{1}$ was elucidated as acetyllycoposerramine M.

Palcernine A (2) was obtained as a colorless block crystal (mp 98-101 $\left.{ }^{\circ} \mathrm{C}\right)$. Its molecular formula $\left(\mathrm{C}_{17} \mathrm{H}_{24} \mathrm{NO}_{3}\right)$ 


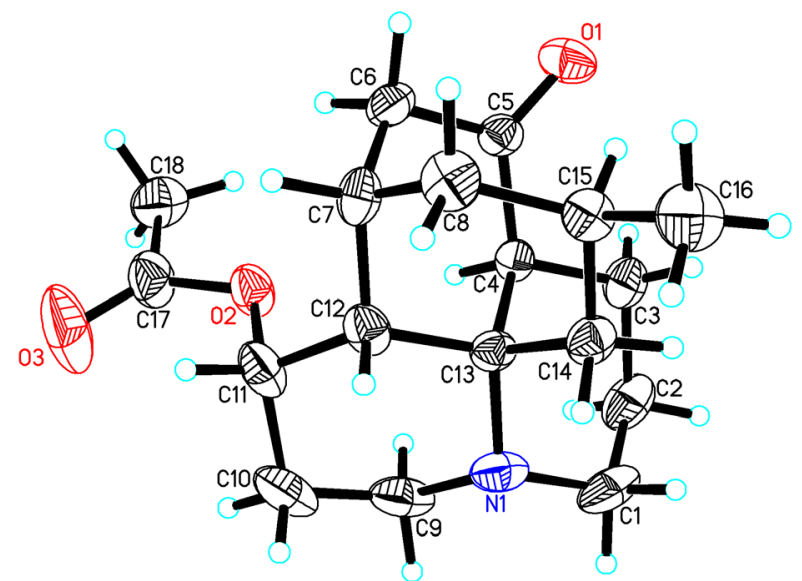

Figure 3. ORTEP drawing of the asymmetric unit of compound $\mathbf{1 .}$

was established on the basis of HRESIMS for the $[\mathrm{M}+\mathrm{H}]^{+}$ ion at $\mathrm{m} / \mathrm{z} 290.1754$ (calcd. 290.1756), implying seven degrees of unsaturation. The IR spectrum showed the presence of hydroxy $\left(3441 \mathrm{~cm}^{-1}\right)$, ketone $\left(1709 \mathrm{~cm}^{-1}\right)$ and $\alpha, \beta$-unsaturated ketone $\left(1631 \mathrm{~cm}^{-1}\right)$ groups. A signal $\delta_{\mathrm{H}} 0.90(\mathrm{~d}, 3 \mathrm{H}, J 6.7 \mathrm{~Hz})$ for a methyl group was observed in the ${ }^{1} \mathrm{H}$ NMR spectrum of 2 (Table 1), and 17 carbon signals for two ketone, one tetrasubstituted double bond, two $\mathrm{sp}^{3}$ quaternary, one methine, nine methylene and one methyl groups were recorded in the ${ }^{13} \mathrm{C}$ NMR and DEPT of 2 (Table 2). Three fragments, a (C-1 to C-3), b (C-9 to $\mathrm{C}-12)$ and $\mathbf{c}(\mathrm{C}-8-\mathrm{C}-15-\mathrm{C}-16)$ were elucidated by the ${ }^{1} \mathrm{H}-{ }^{1} \mathrm{H}$ COSY (correlation spectroscopy) experiments (Figure 4). Based on the HMBC correlations (Figure 4) of H-2a/C-4, H-17a/C-2 \& C-3, H-17a \& H-3a/C-5, H-10b/C-12, H-11ß/C-7 \& C-13, H-8 $\alpha / C-6$, C-7 \& C-12, $\mathrm{H}-15 / \mathrm{C}-13$, and $\mathrm{H}_{3}-16 / \mathrm{C}-14$ \& C-13, a fawcettimine skeleton of 2 was determined, and the double bond was
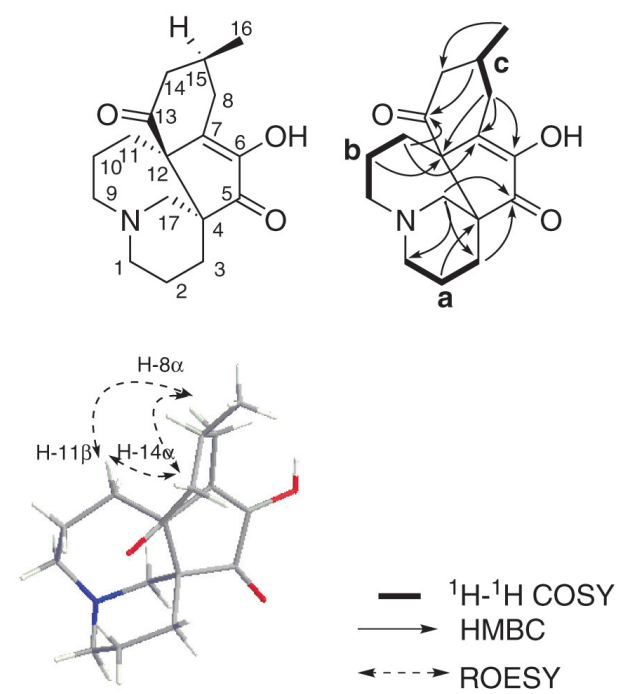

Figure 4. Key 2D NMR correlations of 2. located at C-6, and two ketone groups were located at C-5 and C-13, respectively. After analysis of the molecular formula of $\mathbf{2}$ the presence of a hydroxy functionality in $\mathbf{2}$ was confirmed, possibly being located at C-6.

The relative configuration of partial chiral center of $\mathbf{2}$ could be elucidated, integrating ROESY (rotating-frame Overhauser effect spectroscopy) experiment and analysis on coupling constant. In ROESY spectrum (Figure 4), the cross peaks of $\mathrm{H}-8 \alpha\left(\delta_{\mathrm{H}} 2.66, \mathrm{dd}, J 15.1,8.0 \mathrm{~Hz}\right) / \mathrm{H}-11 \beta\left(\delta_{\mathrm{H}} 1.65\right.$, $\mathrm{dd}, J 14.7,11.8 \mathrm{~Hz}), \mathrm{H}-8 \alpha / \mathrm{H}-14 \alpha\left(\delta_{\mathrm{H}} 2.49\right.$, dd, $J 14.8$, $4.0 \mathrm{~Hz}$ ) and $\mathrm{H}-11 \beta / \mathrm{H}-14 \alpha$ were observed. $\mathrm{H}-14 \alpha$ and $\mathrm{H}-15$ should be in cis configuration due to the coupling constant of $J_{\mathrm{H}-14 \alpha / \mathrm{H}-15} 4.0 \mathrm{~Hz}$ (Table 1). Therefore, the 16$\mathrm{CH}_{3}$ in 2 was $\beta$-oriented, which is rare because the $16-\mathrm{CH}_{3}$ is $\alpha$-oriented in most of the Lycopodium alkaloids. ${ }^{3-5}$ Based on the single-crystal X-ray crystallographic analysis (Figure 5), the absolute configuration of $\mathbf{2}$ was determined to be $4 S, 12 S, 15 S$ in light of the Flack parameter of $0.1(2)$, using anomalous dispersion with copper radiation. ${ }^{20-22}$ Accordingly, 2 was elucidated as shown in Figure 2 and named palcernine A.

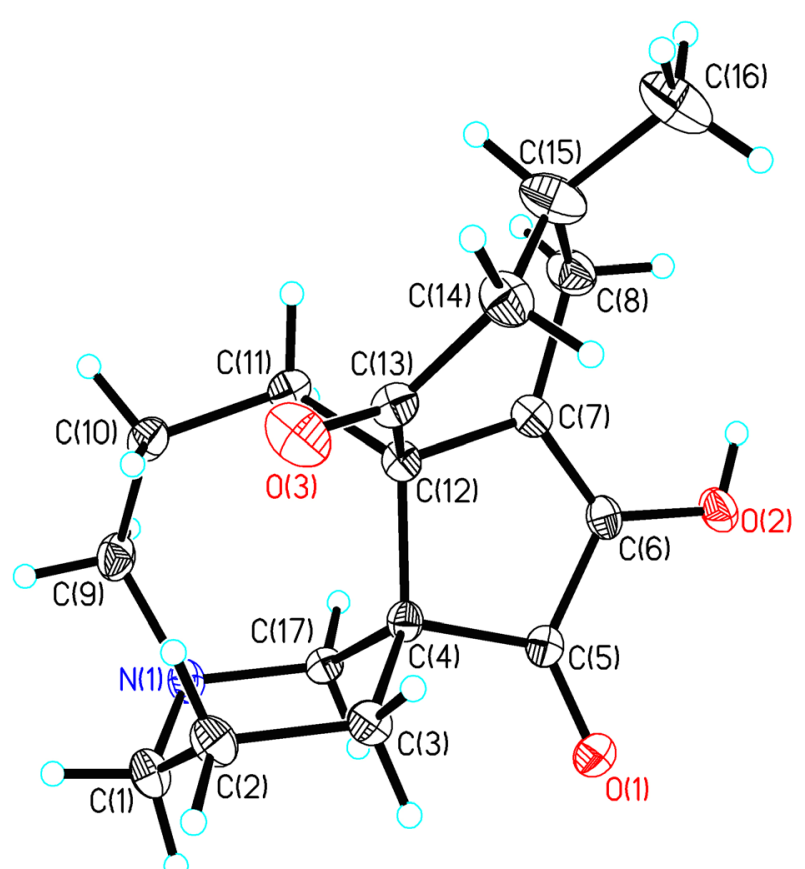

Figure 5. ORTEP drawing of the asymmetric unit of compound 2.

Compounds 1-3 were tested for their inhibition activities against acetylcholinesterase, butyrylcholinesterase and human chronic myelogenous leukemia K562 cells, respectively by the improved Ellman's method, ${ }^{23-27}$ and the MTT method. ${ }^{28}$ However, using these methods no inhibitory activities for the compounds were detected. 


\section{Conclusions}

Twonew Lycopodium alkaloids, acetyllycoposerramine M and palcernine A were isolated from whole plant extracts of Palhinhaea cernua L. together with ten previously identified compounds. The structures of the new compounds were elucidated by spectroscopic methods and single-crystal X-ray diffraction analyses using the Flack parameter. The two new Lycopodium alkaloids along with lycoflexine $N$-oxide were tested for their inhibition activities against acetylcholinesterase, butyrylcholinesterase and human chronic myelogenous leukemia K562 cells, respectively by the improved Ellman's method, and the MTT method. However, using these methods, none of the inhibitive activities of the compounds were detected.

\section{Experimental}

\section{General experimental procedures}

Melting points (mp) were determined using an X-4 melting point apparatus (Yingyu Yuhua Apparatus Factory, Gongyi, P. R. China), and was not adjusted. Bruker SMART APEX-II and Bruker APEX DUO diffractometers using graphite-monochromated $\mathrm{Cu} \mathrm{K}_{\alpha}$ radiations were employed for the intensity data collection, and the structures of compounds were solved by direct methods (SHELXS97). Optical rotations were determined on a JASCO DIP-370 automatic digital polarimeter. UV spectra were recorded on a Shimadzu double-beam 210A spectrometer. IR spectra were recorded on a Bio-Rad FTS-135 infrared spectrophotometer. 1D and 2D NMR spectra were recorded on Bruker AM-400, DRX-500 and Bruker Avance 600 spectrometers with chemical shifts in ppm relative to TMS (tetramethylsilane) as internal standard. ESIMS and HRESIMS were measured using an API QSTAR Pulsar 1 spectrometer, as well as EIMS and HREIMS using a VG Autospec Premier spectrometer. Column chromatography was performed over $\mathrm{Al}_{2} \mathrm{O}_{3}$ (200-300 mesh, Wusi Lt. Co., Shanghai), silica gel $\mathrm{G}$ (80-100 and 300-400 mesh), silica gel $\mathrm{H}$ $(10-40 \mu \mathrm{m})$ and Sephadex LH-20 (40-70 $\mu \mathrm{m}$, Amersham Pharmacia Biotech AB, Uppsala, Sweden). HPLC (highperformance liquid chromatographic) separations were performed using an Agilent 1200 series pump equipped with a diode array detector and a semi-preparative Zorbax SB-C $_{18}(5 \mu \mathrm{m}, \phi 9.4 \times 250 \mathrm{~mm})$ column. TLC (thin layer chromatography) was conducted on precoated $\mathrm{GF}_{254}$ silica gel plates (Qingdao).
Plant material

Whole plant samples of P. cernua, a nodding clubmoss was collected from Liping County of Guizhou Province, P. R. China and identified by Dr. Guang-Wan Hu at the Kunming Institute of Botany, Chinese Academy of Sciences. A voucher specimen (No. SZ09048) was deposited in the Key Laboratory of Economic Plants and Biotechnology, Kunming Institute of Botany.

\section{Extraction and isolation}

The air-dried and powdered sample $(16.5 \mathrm{~kg})$ was three times extracted with $\mathrm{MeOH}(4,4$, and $3 \mathrm{~h})$ at $70{ }^{\circ} \mathrm{C}$. The extracts were partitioned between EtOAc and $1 \% \mathrm{HCl} / \mathrm{H}_{2} \mathrm{O}$. Water-soluble materials were adjusted to $\mathrm{pH} 10$ with $17 \%$ $\mathrm{NaOH} / \mathrm{H}_{2} \mathrm{O}$ solution and extracted with $\mathrm{CHCl}_{3}$, producing an alkaloid-rich extract $(82.0 \mathrm{~g})$. The latter was submitted to a silica gel column $\left(\mathrm{CHCl}_{3} / \mathrm{MeOH}, 1: 0\right.$ to $\left.0: 1\right)$ to produce four fractions: Fr. 1-Fr. 4.

Fr. 1 was partitioned over $\mathrm{C}_{18}$ column eluting with $\mathrm{MeOH} / \mathrm{H}_{2} \mathrm{O}$ (20\% to $100 \%$, v/v). The fraction by $50 \%$ $\mathrm{MeOH} / \mathrm{H}_{2} \mathrm{O}$ was chromatographed over Sephadex LH-20 (MeOH), $\mathrm{Al}_{2} \mathrm{O}_{3}$ [petroleum ether $/ \mathrm{Me}_{2} \mathrm{CO} / \mathrm{NH}_{3} \cdot \mathrm{H}_{2} \mathrm{O}, 80: 10: 1$ $(\mathrm{v} / \mathrm{v} / \mathrm{v})$ ] and silica gel [petroleum ether/ $/ \mathrm{Me}_{2} \mathrm{CO} / \mathrm{NH}_{3} \cdot \mathrm{H}_{2} \mathrm{O}$, 80:10:1 (v/v/v)] columns to obtain two sub-fractions: Fr. 1-50-1 and Fr. 1-50-2. Fr. 1-50-1 was deposited at room temperature, and compound 1 (246.2 $\mathrm{mg}$ ) was crystallized out [petroleum ether/ $\left.\mathrm{Me}_{2} \mathrm{CO}, 9: 1(\mathrm{v} / \mathrm{v})\right]$. The mother solution was evaporated and the residue was subjected to silica gel with petroleum ether $/ \mathrm{Me}_{2} \mathrm{CO}$ $(8: 1, \mathrm{v} / \mathrm{v})$ to yield compound 7 (26.5 mg). Fr. 1-50-2 was submitted to $\mathrm{Al}_{2} \mathrm{O}_{3}$ and silica gel columns and preparative TLC [petroleum ether $/ \mathrm{Me}_{2} \mathrm{CO} / \mathrm{NH}_{3} \cdot \mathrm{H}_{2} \mathrm{O}, 80: 10: 1(\mathrm{v} / \mathrm{v} / \mathrm{v})$ ] to yield compound $3(11.0 \mathrm{mg})$. The fraction by $60 \%$ $\mathrm{MeOH} / \mathrm{H}_{2} \mathrm{O}$ was purified by Sephadex $\mathrm{LH}-20(\mathrm{MeOH})$ and preparative TLC [petroleum ether/ $\mathrm{Me}_{2} \mathrm{CO} / \mathrm{NH}_{3} \cdot \mathrm{H}_{2} \mathrm{O}$, 80:10:1 (v/v/v)] to yield compound $5(14.1 \mathrm{mg})$.

Fr. 2 was chromatographed over $\mathrm{C}_{18}$ column eluting with $\mathrm{MeOH} / \mathrm{H}_{2} \mathrm{O}(30 \%$ to $100 \%$, v/v), and the fraction by $50 \% \mathrm{MeOH} / \mathrm{H}_{2} \mathrm{O}$ was subjected to Sephadex LH-20 $(\mathrm{MeOH})$ and silica gel [petroleum ether $/\left(\mathrm{C}_{2} \mathrm{H}_{5}\right)_{2} \mathrm{NH}$, 100:1 (v/v)] columns to give compounds $4(98.6 \mathrm{mg})$ and $8(16.5 \mathrm{mg})$.

Fr. 3 was chromatographed over $\mathrm{C}_{18}$ column eluting with $\mathrm{MeOH} / \mathrm{H}_{2} \mathrm{O}(30 \%$ to $100 \%$, v/v). The fraction by $50 \% \mathrm{MeOH} / \mathrm{H}_{2} \mathrm{O}$ was separated into two subfractions (Fr. 3-50-1 and Fr. 3-50-2). Fr. 3-50-1 was successively subjected to Sephadex LH-20 (MeOH) and $\mathrm{Al}_{2} \mathrm{O}_{3}\left[\mathrm{CHCl}_{3} / \mathrm{MeOH}, 30: 1\right.$ (v/v)] columns to afford compound 2 (12.5 mg). Fr. 3-50-2 was submitted to 
Sephadex LH-20 (MeOH) and silica gel $\left[\mathrm{CHCl}_{3} / \mathrm{MeOH} /\right.$ $\left.\mathrm{NH}_{3} \cdot \mathrm{H}_{2} \mathrm{O}, 300: 20: 1(\mathrm{v} / \mathrm{v} / \mathrm{v})\right]$ columns to give compound 9 (26.4 mg). The fraction by $60 \% \mathrm{MeOH} / \mathrm{H}_{2} \mathrm{O}$ was subjected Sephadex LH-20 $(\mathrm{MeOH})$ and silica gel $\left[\mathrm{CHCl}_{3} / \mathrm{MeOH}\right.$, $30: 1(\mathrm{v} / \mathrm{v} / \mathrm{v})$ ] columns to obtain compounds $6(138.6 \mathrm{mg})$ and 10 (407.3 mg).

Fr. 4 was chromatographed over $\mathrm{C}_{18}$ column eluting with $\mathrm{MeOH} / \mathrm{H}_{2} \mathrm{O}(30 \%$ to $100 \%$, v/v). The fraction by $40 \% \mathrm{MeOH} / \mathrm{H}_{2} \mathrm{O}$ was purified by Sephadex LH-20 $(\mathrm{MeOH})$, and compound $\mathbf{1 2}(7.4 \mathrm{mg})$ was obtained in light of recrystallization [petroleum ether/MeOH, 9:1 (v/v)]. The fraction by $50 \% \mathrm{MeOH} / \mathrm{H}_{2} \mathrm{O}$ was separated on Sephadex LH-20 (MeOH) and silica gel [ $\left.\mathrm{CHCl}_{3} / \mathrm{MeOH}, 20: 1(\mathrm{v} / \mathrm{v})\right]$ columns to yield compound $\mathbf{1 1}(16.9 \mathrm{mg}$ ).

\section{Acetyllycoposerramine M (1)}

Colorless columnar crystal; mp. $197-198{ }^{\circ} \mathrm{C}$ (from petroleum ether $\left./ \mathrm{Me}_{2} \mathrm{CO}, 9: 1\right) ;[\alpha]_{\mathrm{D}}^{23.6}+45.9$ (c 0.35, $\left.\mathrm{CHCl}_{3}\right) ; \mathrm{UV}\left(\mathrm{CHCl}_{3}\right) \lambda_{\max } / \mathrm{nm}(\log \varepsilon) 241$ (2.94); IR (KBr) $\mathrm{V}_{\max } / \mathrm{cm}^{-1} 1733,1695,1235$ and $1196 ;{ }^{1} \mathrm{H}$ and ${ }^{13} \mathrm{C}$ NMR data, see in Table 1 and Table 2; EIMS $m / z$ (\%) $305\left(\mathrm{M}^{+}\right.$, 83), 262 (38), 246 (95); HREIMS $m / z$ (\%) $305.1995\left(\mathrm{M}^{+}\right.$, $\mathrm{C}_{18} \mathrm{H}_{27} \mathrm{NO}_{3}{ }^{+}$, calcd. 305.1991).

\section{Crystal data for 1}

$\mathrm{C}_{18} \mathrm{H}_{27} \mathrm{NO}_{3}, \mathrm{MW}=305.41$; colorless columnar, size $0.58 \times 0.42 \times 0.36 \mathrm{~mm}^{3}$, orthorhombic, space group $P 212121$; $a=8.43070$ (10) $\AA, b=10.9756$ (2) $\AA, c=17.8783$ (3) $\AA$, $a=b=\gamma=90.00^{\circ}, V=1655.31(5) \AA^{3}, T=296(2) \mathrm{K}, Z=4$, $\rho_{\text {calcd }}=1.226 \mathrm{Mg} \mathrm{m}^{-3}, \mu\left(\mathrm{Cu} \mathrm{K}_{\alpha}\right)=0.7 \mathrm{~mm}^{-1}, F(000)=664$, 10967 reflections in $h(-10 / 10), k(-13 / 12), l(-21 / 21)$, measured in the range $4.73^{\circ} \leq \theta \leq 66.50^{\circ}$, completeness $\theta_{\text {max }}=99.1 \%, 2843$ independent reflections, $R_{\text {int }}=0.0386$, 2878 reflections with $|\mathrm{F}|^{2} \geq 2 \sigma|\mathrm{F}|^{2}, 202$ parameters, 0 restraints, $\mathrm{GOF}=1.116$. Final $R$ index: $R_{1}=0.0424$, $\mathrm{w} R_{2}=0.1089$. $R$ index (all data) $R_{1}=0.0425, \mathrm{w} R_{2}=0.1092$. Flack parameter $0.0(2)$, largest difference peak and hole $=0.222$ and $-0.277 \mathrm{e}^{-3}$. The intensity data for 1 were collected on a Bruker APEX DUO diffractometer with a graphite monochromater, $\mathrm{Cu} \mathrm{K}_{\alpha}$ radiation. The structure of 1 was solved by direct methods (SHELXS97), expanded using difference Fourier techniques, and refined by the program and full-matrix least-squares calculations. The non-hydrogen atoms were anisotropically refined, and hydrogen atoms were fixed at calculated positions. Crystallographic data for the structure of $\mathbf{1}$ were deposited in the Cambridge Crystallographic Data Center (deposition No. CCDC 817948). Copies of the data can be obtained free of charge from the CCDC via www.ccdc.cam.ac.uk.

\section{Palcernine A (2)}

Colorless block crystal; mp. $98-101{ }^{\circ} \mathrm{C}$ (from $\left.\mathrm{Me}_{2} \mathrm{CO} / \mathrm{MeOH}, 5: 1\right) ;[\alpha]_{\mathrm{D}}^{21.7}-21.0(c 0.06, \mathrm{MeOH})$; $\mathrm{UV}(\mathrm{MeOH}) \lambda_{\max } / \mathrm{nm}(\log \varepsilon) 270$ (3.12), 205 (3.44); IR (KBr) $v_{\max } / \mathrm{cm}^{-1} 3441,1709,1631,1384$ and $1102 ;{ }^{1} \mathrm{H}$ and ${ }^{13} \mathrm{C}$ NMR data, see in Table 1 and Table 2; ESIMS $\mathrm{m} / z 290$ $[\mathrm{M}+\mathrm{H}]^{+}, 601[2 \mathrm{M}+\mathrm{Na}]^{+}, 890[3 \mathrm{M}+\mathrm{Na}]^{+} ;$HRESIMS $\mathrm{m} / \mathrm{z} 290.1754[\mathrm{M}+\mathrm{H}]^{+}\left(\mathrm{C}_{17} \mathrm{H}_{24} \mathrm{NO}_{3}\right.$, calcd. 290.1756).

\section{Crystal data for 2}

$\mathrm{C}_{17} \mathrm{H}_{23} \mathrm{NO}_{3}, \mathrm{MW}=289.36$; colorless blocks, size $0.22 \times 0.12 \times 0.08 \mathrm{~mm}^{3}$, orthorhombic, space group $P 212121 ; a=6.35940$ (10) $\AA, b=13.3290$ (2) $\AA$, $c=17.5422$ (3) $\left.\AA, a=b=\gamma=90.00^{\circ}, V=1486.964\right) \AA^{3}$, $T=296(2) \mathrm{K}, Z=4, \rho_{\text {calcd }}=1.293 \mathrm{Mg} \mathrm{m}^{-3}$, $\mu\left(\mathrm{Cu} \mathrm{K}_{\alpha}\right)=0.7 \mathrm{~mm}^{-1}, F(000)=624,2774$ reflections in $h(-6 / 6), k(-14 / 13), l(-19 / 15)$, measured in the range $4.17^{\circ} \leq \theta \leq 64.73^{\circ}$, completeness $\theta_{\max }=71.1 \%, 1617$ independent reflections, $R_{\mathrm{int}}=0.0131,1597$ reflections with $|\mathrm{F}|^{2} \geq 2 \sigma|\mathrm{F}|^{2}, 190$ parameters, 0 restraints, GOF $=1.075$. Final $R$ index: $R_{1}=0.0395, \mathrm{w} R_{2}=0.1191 . R$ index (all data): $R_{1}=0.0400, \mathrm{w} R_{2}=0.1203$. Flack parameter 0.1(2), largest difference peak and hole $=0.318$ and $-0.201 \mathrm{e}^{-3}$. The intensity data for $\mathbf{2}$ were collected on a Bruker SMART APEX-II diffractometer with a graphite monochromater using $\mathrm{Cu} \mathrm{K}_{\alpha}$ radiation. The structure of $\mathbf{2}$ was solved by direct methods (SHELXS97), expanded using difference Fourier techniques, and refined by the program and fullmatrix least-squares calculations. The non-hydrogen atoms were refined anisotropically, and hydrogen atoms were fixed at calculated positions. Crystallographic data for the structure of $\mathbf{2}$ were deposited in the Cambridge Crystallographic Data Center (deposition No. CCDC 831841). Copies of the data can be obtained free of charge from the CCDC via www.ccdc.cam.ac.uk.

\section{Bioactivity test in vitro}

Acetylcholinesterase and tacrine were purchased from Sigma-Aldrich Corporation, $S$-butyrylthiocholine iodide and 5,5-dithiobis-2-nitrobenzoic acid (DTNB) were purchased from Fluka Chemie $\mathrm{GmbH}$ and Acros Organics, respectively. Inhibitory activity of all new compounds against acetylcholinesterase was performed by the improved Ellman's method, and tacrine was used as positive $\left(\mathrm{IC}_{50}=0.20 \mu \mathrm{M}\right)$.

Butyrylcholinesterase was obtained from the blood serum of SD rats which were purchased from Laboratory Animal Center, Guiyang Medical University, Guizhou Province, P. R. China. S-butyrylthiocholine iodide and 
DTNB were purchased from Acros Organics. Inhibitory activity of all new compounds against butyrylcholinesterase was performed by the improved Ellman's method, and tetraisopropylpyrophosphoramide was treated as positive $\left(\mathrm{IC}_{50}=1.35 \mu \mathrm{M}\right)$.

K562 human chronic myelogenous leukemia cell line was purchased from the China Center for Type Culture Collection, Hubei Province, P. R. China. K562 cells were maintained at $37{ }^{\circ} \mathrm{C}$ in RPMI-1640 medium (Hyclone) containing 10\% fetal bovine serum (Hangzhou Sijiqing Biological Engineering Materials Co., Ltd., P. R. China) in an atmosphere of humidified $5 \% \mathrm{CO}_{2}$. The cytotoxic assay was carried out in quintuplicate in 96-well microplates (Corning), and the amount of viable cells at the end of the incubation period was determined by using MTT [3-(4,5-dimethylthiazol-2-yl)-2,5-diphenyltetrazolium bromide] assay. K562 cells were exposed for $24 \mathrm{~h}$ to the solution of all new compounds. Non-treated culture cells were used as a negative control. $\mathrm{IC}_{50}$ was calculated by the GWBASIC software as the concentration $(\mu \mathrm{M})$ of the compounds causing a $50 \%$ inhibition of cell viability. Adriamycin was treated as positive control $\left(\mathrm{IC}_{50}=0.96 \mu \mathrm{M}\right)$.

\section{Supplementary Information}

Supplementary information is available free of charge at http://jbcs.sbq.org.br, as PDF file.

\section{Acknowledgements}

This work was sponsored by the National Natural Science Foundation of China (No. 20972166), the National Basic Research Program of China (973 Program) (No. 2009CB 526512), the Ministry of Education of China through its 111 and 985 Projects (B08044 and MUC 985-9), and the Knowledge Innovation Project of the Chinese Academy of Sciences. We appreciate Dr. Jia-Liang Zhong (at the Shanghai Institute of Pharmaceutical Industry) and Xiao-Nian Li (at the Kunming Institute of Botany) who measured and elucidated the crystal structure. We are also grateful to Adam Nerin (Ph.D. candidate at the City University of New York, USA) and Jeffrey R. Boutain (Ph.D. candidate at the University of Hawaii at Manoa, USA) for editing the English.

\section{References}

1. Zhang, X. C.; Zhang, L. B.; Flora Reipublicae Popularis Sinicae; Science Press: Beijing, China, 2004, ch. 6(3).

2. Chinese Herbs Edition Board; Chinese Herbs, Shanghai Science and Technology Press: Shanghai, China, 2005, ch. 2.
3. Hirasawa, Y.; Kobayashi, J.; Morita, H.; Heterocycles 2009, 77, 679.

4. Ayer, W. A.; Nat. Prod. Rep. 1991, 8, 455.

5. Ma, X.; Gang, D. R.; Nat. Prod. Rep. 2004, 21, 752.

6. Ishiuchi, K.i.; Kubota, T.; Ishiyama, H.; Hayashi, S.; Shibata, T.; Kobayashi, J.; Tetrahedron Lett. 2011, 52, 289.

7. Ishiuchi, K.i.; Kubota, T.; Ishiyama, H.; Hayashi, S.; Shibata, T.; Mori, K.; Obara, Y.; Nakahata, N.; Kobayashi, J.; Bioorg. Med. Chem. 2011, 19, 749.

8. Katakawa, K.; Mito, H.; Kogure, N.; Kitajima, M.; Wongseripipatana, S.; Arisawa, M.; Takayama, H.; Tetrahedron 2011, 67, 6561 .

9. Zhao, F. W.; Sun, Q. Y.; Yang, F. M.; Hu, G. W.; Luo, J. F.; Tang, G. H.; Wang, Y. H.; Long, C. L.; Org. Lett. 2010, 12, 3922.

10. Kitajima, M.; Takayama, H.; Topics in Current Chemistry; Springer-Verlag: Heidelberg, 2011, vol. 1.

11. Takayama, H.; Katakawa, K.; Kitajima, M.; Yamaguchi, K.; Aimi, N.; Tetrahedron Lett. 2002, 43, 8307.

12. Nakashima, T. T.; Singer, P. P.; Browne, L. M.; Ayer, W. A.; Can. J. Chem. 1975, 53, 1936.

13. Burnell, R. H.; Taylor, D. R.; Tetrahedron 1961, 15, 173.

14. MacLean, D. B.; Can. J. Chem. 1963, 41, 2654.

15. Anet, F. A. L.; Ahmad, M.; Khan, N. H.; Can. J. Chem. 1962, $40,236$.

16. Burnell, R. H.; Mootoo, B. S.; Taylor, D. R.; Can. J. Chem. 1960, 38, 1927.

17. Laemmerhold, K. M.; Breit, H.; Angew. Chem., Int. Ed. 2010, 49, 2367.

18. Braekman, J. C.; Nyembo, L.; Bourdoux, P.; Kahindo, N.; Hootele, C.; Phytochemistry 1974, 13, 2519.

19. Takayama, H.; Katakawa, K.; Kitajima, M.; Yamaguchi, K.; Aimi, N.; Chem. Pharm. Bull. 2003, 51, 1163.

20. Flack, H.; Acta Crystallogr., Sect. A: Found. Crystallogr. 1983, $39,876$.

21. Flack, H. D.; Bernardinelli, G.; J. Appl. Crystallogr. 2000, 33, 1143.

22. Sheldrick, G. M; SHELXS-97, Program for Crystal Structure Solution; University of Gottingen: Gottingen, Germany, 1997.

23. Ellman, G. L.; Courtney, K. D.; Andres, V. J.; Featherstone, R. M.; Biochem. Pharmacol. 1961, 7, 88.

24. Rhee, I. K.; Appels, N.; Hofte, B.; Karabatak, B.; Erkelens, C.; Stark, L. M.; Flippin, L. A.; Verpoorte, R.; Biol. Pharm. Bull. 2004, 27, 1804.

25. Sun, Q. Y.; Yang, F. M.; Chin. Pharm. Bull. 2008, 24, 1387.

26. Vogel, H. G.; Vogel, W. H.; Drug Discovery and Evaluation: Pharmacological Assays; Springer: New York, 2008.

27. Yang, F. M.; Sun, Q. Y.; Chin. Pharm. Bull. 2009, 25, 690.

28. Mosmann, T.; J. Immunol. Methods 1983, 65, 55.

Submitted: July 6, 2011

Published online: December 1, 2011 